\title{
PROSPECTS OF USAGE OF PEA PROTEIN ISOLATE IN BUTTERY PASTES TECHNOLOGY
}

\author{
O. Kochubei-Lytvynenko, V. Pasichnyi, N. Yushchenko, O. Yatsenko, \\ U. Kuzmyk \\ National University of Food Technologies
}

\begin{tabular}{l} 
Key words: \\
Buttery paste \\
Vegetable albumen \\
Pea protein isolate \\
Strain rate \\
\hline
\end{tabular}

Article history:

Received 09.11.2018

Received in revised form

23.11.2018

Accepted 10.12.2018

Corresponding author:

O. Kochubei-Lytvynenko

E-mail:

okolit@email.ua

\begin{abstract}
For formation of appropriate structure of buttery pastes, which are characterized by high moisture content and provision of their stability during storage, search for effective natural functional and technological components is relevant. Proteins are among them, they would not only perform technological functions, but also serve as additional enriching component.
\end{abstract}

Pea protein isolate holds a specific place among other vegetable proteins, as it has sufficiently balanced amino acid composition; almost completely deprived of taste and smell, common to legumes; does not contain antinutrients; has high water binding capacity and emulsifying characteristics; is not included to a group of products, that may cause allergy. The digestion rate of the isolate is approximately $98 \%$.

Isolate should be previously mixed with skimmed milk, water rational value was determined as 1:8, which allows to provide protein hydration and deployment of its space structure. Practicability of pea protein isolate hydration during 24 hours at a temperature $(6 \pm 2)^{\circ} \mathrm{C}$ was proved; that would allow to obtain a homogeneous systemwith a higher indicator of stress gradient, rather than without holding. Upon the indicator of limit stress through variable strain rate of model samples, the technological parameters of pea protein isolate processing were determined: temperature $(82 \pm 2)^{\circ} \mathrm{C}$, process duration - $10 \ldots 15$ minutes with consequent cooling to $(20 \pm 2)^{\circ} \mathrm{C}$. It was determined, that jellies based on pea protein isolate are flexible systems and have enough firmness and thixotropic properties. It was suggested to produce buttery pastes through mixing hydrated pea protein isolate and a fatty base with consequent mechanical processing to obtain homogeneous mass. Possibility of appending hydrated pea protein isolate into a fatty base in amount under $2.5 \%$ without change in organoleptic indicators was established. The necessity of complex stabilization systems creation through production of buttery pastes with pea protein isolate was proved. 


\title{
ПЕРСПЕКТИВИ ВИКОРИСТАННЯ \\ ІЗОЛЯТУ ГОРОХОВОГО ПРОТЕЇНУ \\ У ТЕХНОЛОГІї МАСЛЯНИХ ПАСТ
}

\author{
О.В. Кочубей-Литвиненко, В.М. Пасічний, Н.М. Ющенко, О.В. Яценко, \\ У.Г. Кузьмик \\ Національний університет харчових технологій
}

Для формування належної структури масляних паст, що характеризуються підвищеним вмістом вологи, та забезпечення їх стабільності під час зберігання, актуальним є пошук ефективних натуральних функиіональнотехнологічних компонентів, серед яких - білки, що будуть не тільки виконувати технологічні функиї̈, а й слугувати додатковим збагачуючим компонентом.

Ізолят горохового протеїну займає особливе місие серед рослинних білків, оскільки має достатньо збалансований амінокислотний склад, практично повністю позбавлений смаку $і$ запаху, характерного для бобових, не містить антипоживних речовин, має високі вологозв'язуючі та емульгуючі властивості, не входить до групи продуктів, що можуть викликати алергії. Ступінь засвоєння ізоляту становить близько 98\%.

Ізолят попередньо передбачено змішувати зі знежиреним молоком, при иьому ращіональне значення гідромодуля - 1:8, щзо забезпечує гідратацію білка та розгортання його просторової структури. Доведено доиільність гідратаиії ізолята горохового протеїну протягом 24 годин за температури $(6 \pm 2)^{\circ} \mathrm{C}$, що дає змогу отримати гомогенну систему із вищим показником градієнта напруження, ніж без витримування. Визначено технологічні параметри оброблення ізоляту горохового протеїну: температура $-(82 \pm 2)^{\circ} \mathrm{C}$, тривалість процесу - $10 \ldots 15$ хвилин, подальше охолодження - до $(20 \pm 2)^{\circ} \mathrm{C}$. $3^{\prime}$ ясовано, щчо гелі на основі ізоляту горохового протеїну є пластичними системами, мають достатню міцність і тиксотропні властивості. Запропоновано виробляти масляні пасти змішуванням гідратованого ізоляту горохового протеїну із жировою основою з подальшим механічним обробленням до отримання гомогенної маси. Встановлено можливість введення ізоляту горохового протеїну до жирової основи у кількості до 2,5\% без змін органолептичних показників. Доведено необхідність створення комплексних стабілізаційних систем при виробництві масляних паст з ізолятом горохового протеӥну.

Ключові слова: масляні пасти, рослинні білки, ізолят горохового білка, швидкість деформації.

Постановка проблеми. Масляні пасти - емульсійні молочні продукти, що часто позиціонуються на споживчому ринку як більш низькокалорійні аналоги вершкового масла за достатньо невисокого вмісту жиру - від 40,0 до 49,9\%. Для формування належної структури масляних паст з підвищеним вмістом вологи та забезпечення їх стабільності під час зберігання актуальним 
є пошук ефективних натуральних функціонально-технологічних компонентів і комплексних стабілізаторів структури.

Перспективним є використання білків - молочного, концентрату сироваткових білків і рослинних білків, зокрема сої, коноплі, гороху, що будуть не тільки виконувати технологічні функції, а й слугувати додатковим збагачуючим компонентом.

Ізолят горохового протеїну займає собливе місце серед рослинних білків, оскільки має достатньо збалансований амінокислотний склад, практично повністю позбавлений смаку і запаху, характерного для бобових, не містить антипоживних речовин, має високі вологозв'язуючі та емульгуючі властивості $[1 ; 2]$.

Крім того, при виділенні ізоляту горохового білка не використовують хімічні речовини, а виробництво складається тільки із сухого (очищення, розмелювання) та вологого (сепарація, фільтрація) процесів обробки сировини тощо [3; 4]. Під час виробництва здійснюється екстрагування водою, без використання органічних розчинників.

Перспективним напрямом наукових досліджень $є$ наукове обгрунтування використання ізоляту горохового протеїну у складі рецептур масляних паст 3 урахуванням його біологічної цінності, функціонально-технологічних характеристик і безпечності.

Аналіз останніх досліджень і публікацій. Науковцями Національного університету харчових технологій розроблено технологію масляної пасти, стабілізованої білково-полісахаридним комплексом [5]. Основу стабілізаційної системи складали молочні білки. 3 метою підвищення ефективності системи до їі складу вводились полісахариди - активні структуроуворювачі. Безперечно, молочні білки є найбільш біологічно повноцінними. Їх поєднання із жировою основою у складі масляних паст $є$ більш органічним. Але 3 огляду на економічну складову (рослинні білки мають у $3-4$ рази нижчу вартість) використання рослинних білків заслуговує на увагу.

3 аналізу досліджень відомо, що гороховий білок як інгредієнт має безліч переваг порівняно з іншими рослинними білками. А саме: є функціональним інгредієнтом - володіє волого- і жирозв'язуючими властивостями та має нейтральний смак, засвоюваність такого білка становить близько 98\%. Його емульгуюча здатність дає змогу створити необхідну текстуру продукту, стійку до теплової обробки під час технологічного процесу. Ізолят горохового протеїну є концентрованим джерелом легкозасвоюваного білка, його амінокислотний склад наближений до «ідеального білка» порівняно 3 іншими рослинними білками [6; 7].

Вміст незамінних амінокислот білка гороху, якщо порівняти 3 іншими рослинними білками та «ідеальним білком», наведено у табл. 1.

Таблиця 1. Порівняльна характеристика амінокислотного складу ізоляту білка гороху з молочним та «ідеальним» білком [7; 8]

\begin{tabular}{|c|c|c|c|c|c|}
\hline \multirow{2}{*}{$\begin{array}{c}\text { Назва } \\
\text { амінокинної }\end{array}$} & «деальний білок» (ФАО/ВОЗ) & \multicolumn{2}{|c|}{ Молочнй білок } & \multicolumn{2}{|c|}{ Ізолят горохового білка } \\
\cline { 2 - 6 } & мг/ 1 г білка & $\begin{array}{c}\text { МГ/ 1 г } \\
\text { білка }\end{array}$ & Скор, \% & мг/ 1 г білка & Скор, \% \\
\hline 1 & 2 & 3 & 4 & 5 & 6 \\
\hline Ізолейцин & 40 & 43,3 & 108,2 & 45,6 & 114 \\
\hline
\end{tabular}




\begin{tabular}{|c|c|c|c|c|c|}
\hline \multicolumn{4}{c}{ Продовження табл. 1 } \\
\hline 1 & 2 & 3 & 4 & 5 & 6 \\
\hline Лейцин & 70 & 92,8 & 132,3 & 83,7 & 120 \\
\hline Лізин & 55 & 58,8 & 117,6 & 74,9 & 136 \\
\hline $\begin{array}{c}\text { Метіонін } \\
\text { цистеїн }\end{array}$ & 35 & 34,0 & $\mathbf{9 7 , 1}$ & 23,7 & $\mathbf{6 8}$ \\
\hline $\begin{array}{c}\text { Фенілаланін } \\
\text { тирозин }\end{array}$ & 60 & 83,5 & 137 & 92,4 & 154 \\
\hline Треонін & 40 & 37,1 & 92,7 & 39 & 98 \\
\hline Валін & 50 & 52,6 & 105,2 & 49,3 & 99 \\
\hline
\end{tabular}

Лімітуючими амінокислотами, подібно до молочного білка, є метіонін 3 цистеїном. Причому амінокислотний скор за сумою цих амінокислот є дещо нижчим. Слід зазначити, що гороховий протеїн містить до 18\% ВСАА (амінокислот з розгалуженим ланцюгом) та, на відміну від білка сої, практично не містить ізофлавонів. Горох не входить до списку продуктів, що можуть викликати алергійні реакції і рекомендується як безалергенне джерело білка.

Мета дослідження: обгрунтувати доцільність використання ізоляту горохового протеїну в технології масляних паст.

Матеріали і методи. Дослідження здійснювали в межах науково-дослідної роботи (НДР) «Наукові засади розроблення ресурсоощадних технологій білоквмісних поліфункціональних концентратів для харчових продуктів цільового призначення» (держреєстрація № 0117U001243), Україна.

Як об'єкт дослідження використовували гідратований ізолят горохового білка (виробник BRAG, Австрія). Модельні зразки готували на основі знежиреного молока (масова частка білка 3,2\%). Для цього сухий компонент у визначених умовами досліду кількостях при безперервному перемішуванні додавали до знежиреного молока з температурою $(20 \pm 2)^{\circ} \mathrm{C}$.

Надалі модельні зразки при безперервному перемішуванні нагрівали до температури $(82 \pm 2)^{\circ} \mathrm{C}$ з тривалістю процесу 5, 10 та 15 хв, 3 подальшим охолодженням до $(20 \pm 2)^{\circ} \mathrm{C}$. Більш тривале витримування виявилось недоцільним через втрати вологи під час термічного оброблення.

3 метою визначення впливу тривалої гідратації на структурно-механічні властивості модельних систем, після змішування ізоляту горохового білка із знежиреним молоком їх витримували протягом 24 годин за температури $(6 \pm 2)^{\circ} \mathrm{C}$, далі здійснювали температурне оброблення описаним вище способом.

Готувались модельні зразки за наведеним вище способом, гідромодуль, тобто співвідношення між сухим компонентом (ізолятом горохового протеїну) та гідратуючим середовищем (знежирене молоко), встановлювали як $1: 6 ; 1: 8 ; 1: 10$.

Реологічні властивості модельних зразків визначали на ротаційному віскозиметрі «Реотест-2» 3 вимірювальною системою циліндр - циліндр $\mathrm{S} / \mathrm{N}$ шляхом зняття кривих кінетики деформації (течії) на кафедрі технології м'яса і м'ясних продуктів Національного університету харчових технологій.

Вимірювання проводили за температури $20^{\circ} \mathrm{C}$. Вимірювальний циліндр (ротор) $\mathrm{N}$ обирали 3 таким розрахунком, щоб градієнтний шар розповсюджувався на всю товщину шару продукту, розміщеного в кільцевому зазорі 
вимірювального пристрою віскозиметра. Вимірювання напруги зсуву $\theta$ (Па) проводили за 12 значеннями градієнта швидкості зсуву $\gamma$ у діапазоні від 0 до $100 \mathrm{c}^{-1}$ під час прямого і зворотного ходу. Для цього знімали показники $\alpha$ при максимальному куті відхилення стрілки на шкалі приладу [9].

Напругу зсуву (Па) розраховували за формулою:

$$
\theta=Z \cdot \alpha,
$$

де $Z$ - константа циліндра, Па; $\alpha-$ вимірюваний показник, кількість поділок за шкалою приладу.

Поєднуваність ізоляту горохового білка із жировою основою та максимально рекомендована кількість його введення визначалась органолептично. Для цього здійснювалась гідратація ізоляту горохового білка на знежиреному молоці з подальшим тепловим обробленням. Отримували модельні зразки масою по 100 г. Для цього розраховані кількості гідратованої суміші з температурою не вище $22^{\circ} \mathrm{C}$ змішувалась із жировою основою (вершкове масло масовою часткою жиру $72,5 \%$, вологи - 25,0\%), після чого здійснювалось вимішування до отримання однорідної маси. Зразки охолоджували до температури $(12 \pm 1)^{\circ} \mathrm{C}$.

Викладення основних результатів дослідження. Оскільки ізолят горохового білка володіє водопоглинальними властивостями, для максимального використання технологічних можливостей цієї добавки необхідним є уточнення режимів гідратації та подальшого введення системи до складу продукту.

Залежність градієнта напруження від швидкості деформації модельних зразків за різного гідромодуля наведено на рисунку.

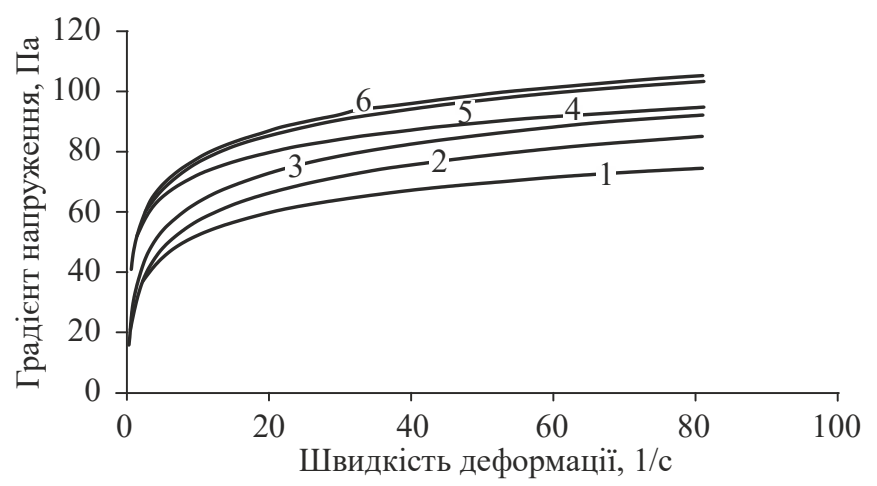

1 - гідратований ізолят;

2 - гідратований ізолят з подальшою температурною обробкою;

3 - гідратований ізолят з витримкою 24 год;

4 - гідратований ізолят з витримкою 24 год та подальшою температурною обробкою тривалістю 5 хв;

5 - гідратований ізолят з витримкою 24 год та подальшою температурною обробкою тривалістю 10 хв;

6 - гідратований ізолят з витримкою 24 год та подальшою температурною обробкою тривалістю 15 хв.

Рис. Залежність градіснта напруження, гідратованого на знежиреному молоці ізоляту горохового протеїну, від швидкості деформації модельних зразків (гідромодуль 1:6) 
Встановлено, що залежність градієнта напруження від швидкості деформації за різних умов підготовки сухого ізоляту $\epsilon$ подібною, але абсолютне значення градієнта напруження було вищим для ізоляту, який витримувався у гідратаційному середовищі протягом 24 годин 3 подальшим тепловим обробленням за температури $(82 \pm 2)^{\circ} \mathrm{C}$ протягом 10 хвилин. Градієнт напруження був незначно вищим для зразків, підготовлених аналогічним чином, але 3 термічними обробленням протягом 15 хвилин.

На наступному етапі визначали раціональне співвідношення між ізолятом горохового протеїну та гідратуючим середовищем. Показники градієнта напруження модельних зразків (при сталій швидкості деформації) за змінних значень гідромодуля наведені у табл. 2 (нумерація зразків - відповідно до рисунка).

Таблиця 2. Градієнт напруження модельних зразків при сталій швидкості деформації за змінних значень гідромодуля

\begin{tabular}{|c|c|c|c|c|c|c|c|c|}
\hline \multirow{5}{*}{ Зразок, № } & \multicolumn{8}{|c|}{ Градієнт напруження, Па } \\
\hline & \multicolumn{8}{|c|}{ Швидкість деформації, 1/с } \\
\hline & \multicolumn{2}{|c|}{20} & \multicolumn{2}{|c|}{40} & \multicolumn{2}{|c|}{60} & \multicolumn{2}{|c|}{80} \\
\hline & \multicolumn{8}{|c|}{ Гідромодуль } \\
\hline & $1: 8$ & $1: 10$ & $1: 8$ & $1: 10$ & $1: 8$ & $1: 10$ & $1: 8$ & $1: 10$ \\
\hline 1 & 60 & 58 & 64 & 60 & 70 & 64 & 72 & 68 \\
\hline 2 & 62 & 58 & 78 & 65 & 82 & 72 & 86 & 78 \\
\hline 3 & 68 & 62 & 86 & 72 & 86 & 80 & 92 & 82 \\
\hline 4 & 68 & 62 & 88 & 76 & 92 & 80 & 95 & 84 \\
\hline 5 & 80 & 70 & 88 & 82 & 98 & 88 & 102 & 94 \\
\hline 6 & 80 & 72 & 90 & 82 & 98 & 90 & 102 & 96 \\
\hline
\end{tabular}

Встановлено, що показник градієнта напруження модельних зразків, приготованих за гідромодуля $1: 6$, незначно відрізняється від відповідного показника для зразків, приготованих за гідромодуля 1: 8. Це свідчить про те, що значення гідромодуля 1:6 є недостатнім для гідратації білка та розгортання його просторової структури.

При збільшенні гідромодуля до 1:10 спостерігалось зниження показника градієнта напруження, що є природним при збільшенні вмісту вільної вологи. Отже, достатнім для гідратації білка є значення гідромодуля 1:8.

На наступному етапі здійснювали порівняльний аналіз органолептичних показників модельних зразків, виготовлених за гідромодуля 1:8 із та без попереднього витримування протягом 24 годин. Встановлено, що зразок, при приготуванні якого суміш витримувалась протягом 24 годин, мав характерний для цього виду рослинної сировини смак і злегка виражений запах, білий із злегка сіруватим відтінком колір та густу, однорідну мастку консистенцію. При аналізі зразків, що були вироблені без попереднього витримування перед тепловим обробленням, були виявлені окремі грудочки, що спричиняли появу пісчанистої консистенції. Тому витримування суміші перед тепловим обробленням $\epsilon$ обов'язковою технологічною операцією підготовки компонента.

Вивчено можливість введення ізолята горохового білка до жирової основи та максимально доцільну кількість його введення.

Кількість доданого до жирової основи ізолята змінювали від 1,0 до 5,0\% 3 інтервалом у $0,5 \%$. Підготовку ізолята горохового білка здійснювали визначеним вище чином. 
Встановлено, що із збільшенням кількості ізолята горохового білка до 2,5\% відчутних змін не відбувалось, при підвищенні кількості до 3,0\% відчувався слабкий прісний присмак бобових. При збільшенні кількості доданого ізоляту до 4,0\% смак ставав більш вираженим, консистенція, хоча і залишалась однорідною, тактильно під час розжовування продукту з'являлось відчуття неоднорідності зразка, зниження відчуття ніжності та пластичності.

Очевидно, така кількість введення ізоляту білка гороху є недостатньою для отримання масляних паст та вимагає додаткового використання стабілізуючих компонентів. Доцільним $є$ створення комплексних стабілізаційних систем із залученнм активних структуроутворювачів, які б виявляли ефект синергізму з ізолятом білка гороху.

\section{Висновки}

1. Обгрунтовано доцільність використання в технології масляних паст ізолята горохового білка як вологоутримуючого компонента та джерела легкозасвоюваного рослинного білка.

2. Визначено технологічні параметри підготовки ізолята горохового білка: гідратація на знежиреному молоці протягом 24 годин за температури $(6 \pm 2)^{\circ} \mathrm{C}$ (гідромодуль 1:8) 3 подальшим нагріванням до температури $(82 \pm 2)^{\circ} \mathrm{C} 3$ тривалістю процесу 15 хвилин та охолодженням до $(20 \pm 2)^{\circ} \mathrm{C}$.

3. Встановлено можливість введення ізоляту білка гороху до жирової основи у кількості до 2,5\% без змін органолептичних показників

4. Доведено необхідність створення комплексних стабілізаційних систем при виробництві масляних паст з ізолятом білка гороху.

\section{Лiтература}

1. Магзумован Н.В., Малиновская Е.Е., Келенян М.В. Изучение возможности применения горохового белка при производстве колбас вареной ассортиментной группы. Харчова наука і технологія. 2013. № 2. С. 20-22.

2. Осипова Г.А., Корячкина С.Я. Использование белковых изолятов в производстве макаронных изделий. Современные наукоемкие технологии. 2006. №. 7. С. 91-93.

3. Бруно Ж. Гороховый белок: лучше, чем просто функциональная добавка. Журнал мясная индустрия. 2007. Вып. 10. С. $40-41$.

4. Волчков А. Влияние изолятов растительных белков на пищевую ценность макаронных изделий. Хлебопродукты. 2009. №. 1. С. 42- 44.

5. Ющенко Н.М., Пасічний В.М., Яценко О.В. Дослідження функціонально-технологічних властивостей білково-полісахаридних комплексів та їх використання у технології масляних паст. Науковий вісник ЛНУВМБТ імені С.3. Гюсищького. 2017. Т. 19, № 75. С. 45-50.

6. Бобков С.В., Уварова О.В. Перспектива использования гороха для производства изолятов запасных белков. Земледелие. 2012. №. 8. С. 22-25.

7. Грищенко Т.В., Черныш Л.Н., Махинько В.Н. Перспективность и особенности использования изолята горохового белка в хлебопечении. Мир науки и инноваиий. Иваново: Научный мир. 2015 Вып. 2, Т. 4. С. 46- 49.

8. Оценка биологической полноценности белков молока / Камиль Аль-Бази Мезхер, В.Г. Прудников, С.О. Шаповалов, И.А. Ионов, Е.В. Руденко. Науково-технічний бюлетень. 2013. № 109, Ч. 2. С. 57-63.

9. PasichnyiV., Yushchenko N., Mykoliv I., Kuzmyk U. Structure Stabilization of Fermented-Milk Pastes. Ukrainian Food Journal. 2015. C. 402-410. 